\title{
BIOÉTICA E SUA RELEVÂNCIA PARA A EDUCAÇÃO
}

\author{
Bioethics and its relevance to education
}

\author{
Mário Antônio Sanches ${ }^{a}$, Waldir Souza ${ }^{b}$ \\ ${ }^{a}$ Professor de Teologia e Bioética no Bacharelado em Teologia da PUCPR, Curitiba, \\ PR - Brasil, e-mail: m.sanches@pucpr.br \\ b Professor de Teologia no Bacharelado em Teologia da PUCPR, Curitiba, PR - Brasil, \\ e-mail: waldir.souza@pucpr.br
}

\section{Resumo}

Este trabalho é uma aproximação do debate em Bioética para a área da Educação. A Bioética tem como propósito avaliar o impacto do avanço científico nas ciências biológicas sobre a vida em toda a sua complexidade. Deste modo, analisam-se três aspectos considerados importantes para a educação: o impacto das pesquisas em biologia sobre a visão de ser humano, a necessária superação de uma visão antropocêntrica arrogante e a reconhecida e clara importância que a bioética atribui à interdisciplinaridade. Estes aspectos amplamente discutidos - com vasta produção bibliográfica em Bioética - estão intrinsecamente ligados à Educação e o desenvolvimento desta interrelação pode se tornar proveitoso para ambas as partes.

Palavras-chave: Bioética; Educação; Visão de mundo; Interdisciplinaridade.

Rev. Diálogo Educ., Curitiba, v. 8, n. 23, p. 277-287, jan./abr. 2008 


\section{Abstract}

This work is an approach to the debates in Bioethics that are relevant do Education. Bioethics has as purpose to evaluate the impact of scientific development in the area of Biological Sciences about life and its all complexity. Therefore, it's analyzed three aspects seen as important to Education: the impact of research in biology on the way we see the human being; a necessary overcoming of an arrogant anthropocentric vision and the clear and relevant value that Bioethics gives to interdisciplinarity. Theses aspects largely studied - with large bibliographic production in Bioethics - are intrinsically linked to Education, and the development of these interaction can be very useful to both areas.

Keywords: Bioethics; Education; Vision of world; Interdisciplinarity.

Em alguns setores a Bioética é vista como uma área do conhecimento já bastante consolidada, porém na área da Educação ela ainda é pouco conhecida. Por isso se faz necessária uma rápida abordagem e caracterização desta nova disciplina e, para alguns, desta nova ciência, ou ainda um campo multidisciplinar (DURAND, 2003, p. 111).

Os profissionais da saúde por muito tempo têm se preocupado com a ética, no exercício de suas atividades. Tendo em vista que a bioética teve seu início há menos de meio século, ela não pode ser apontada como a responsável pelo despertar da reflexão ética no mundo da saúde. Na verdade, a reflexão ética envolvendo a saúde vem com o despertar da própria reflexão ética em cada sociedade, como na Índia, no povo hebreu, na China antiga, na Grécia e em outras tradições antigas.

A Bioética, portanto, não rejeita a milenar reflexão que os diferentes povos acumularam sobre ética, mas, paradoxalmente, ela nasce exatamente da perplexidade frente à novidade e da percepção de que problemas atuais trazem novos e estonteantes desafios. Foi o desenvolvimento das ciências biológicas e os avanços realizados no campo da saúde que fizeram surgir a bioética como uma ponte que liga a reflexão que se dá no complexo e plural universo da ética, com os avanços ocorridos nas biociências e no mundo da saúde (SCHRAMM, 1998, p. 218). A Bioética é nova como igualmente novos são inúmeros procedimentos na área da saúde, tais como: transplante de órgãos, terapia genética, terapia celular, reprodução assistida e muitos outros.

Rev. Diálogo Educ., Curitiba, v. 8, n. 23, p. 277-287, jan./abr. 2008 
A Bioética é, deste modo, o fruto do esforço de todos aqueles que entendem que cada novo movimento das biociências precisa ser acompanhado por um outro movimento: o da reflexão em outras áreas do conhecimento humano sobre esta mesma novidade. Cada conquista inusitada precisa ser acompanhada de uma reflexão sobre as suas conseqüências para a sociedade. Cada novo procedimento precisa ser seguido de orientações que possam garantir a continuidade e o aprimoramento do processo de cuidar. Por isso, em alguns momentos, a Bioética aponta caminhos seguros (JONAS, 1984, p. 21) e em outros momentos defende grupos vulneráveis (MACKLIN, 2003, p. 59) num esforço contínuo de extrair princípios (BEUCHAMP; CHILDRESS, 1994, p. 120) que possam orientar a prática.

Por causa do grande desenvolvimento da pesquisa em nosso país, a regulamentação sobre ética em pesquisa envolvendo seres humanos e outros animais se torna cada vez mais relevante, para que brasileiros não se tornem cobaias de grandes empresas estrangeiras que realizam pesquisas em diversos países. É urgente nos alertarmos e nos posicionarmos contra as tentativas de países ricos imporem um duplo padrão ético em pesquisa (GRECO, 2005, p. 36), como se as comunidades carentes pudessem ser sujeitos de pesquisas jamais aprovadas nem toleradas nas comunidades abastadas dos países onde a pesquisa foi planejada. A Bioética apóia a pesquisa e sabe que o desenvolvimento científico precisa dela, mas insiste em declarar que a pesquisa não pode ser atropelada pelos ditames do mercado.

Um exemplo é a Lei n. 11.105/2005 que trata de biossegurança e acaba por regulamentar um novo campo de pesquisa científica no Brasil. No que diz respeito ao âmbito científico, a lei regulamenta o processo e os mecanismos para a utilização de células tronco em pesquisas, bem como dos organismos geneticamente modificados, que inclui os organismos transgênicos. Assim, esta lei libera a ação dos cientistas que há muito tempo requerem uma postura do poder legislativo para a liberação de diversos projetos de pesquisa que aguardavam essas determinações, tanto para as pesquisas realizadas sob a tutela governamental, como aquelas financiadas pelo contingente privado.

Os organismos geneticamente modificados nos remetem às nossas fantasias, eles atinam nossos sonhos mais antigos de "quimeras", "magia" e "milagres", um "Mundo Novo" de possibilidades infinitas. Assim também o são as inúmeras questões que se levantam diante dessas mesmas possibilidades. Boa parte da sociedade se mostrou desconfortável diante dos caminhos que resultaram na aprovação de uma legislação que envolve temas tão polêmicos sob o mesmo teto legal como o são os transgênicos e as pesquisas envolvendo células-tronco embrionárias. Não passaram despercebidos muitos detalhes importantes que, como sempre, revelam a fragilidade do poder legislativo diante de pressões externas e de outros interesses que se maquiam de progresso científico e investem pesadas somas nas biotecnologias.

Rev. Diálogo Educ., Curitiba, v. 8, n. 23, p. 277-287, jan./abr. 2008 
Reflexões e decisões sobre tais temas não podem ficar restritas ao âmbito da biociência, de modo que o aprofundamento da Bioética e seu engajamento político têm sido defendidos ultimamente (GARRAFA; PORTO, 2003, p. 35), pois em saúde não basta planejar, é necessário incluir todos no planejamento (SIQUEIRA, 1998, p. 79). Sem a dimensão social, a bioética perde uma das dimensões fundamentais para se discutir toda problemática que envolve decisão ética e por isso o humano fica comprometido no processo. Márcio Fabri dos Anjos (1988, p. 232) nos alerta: "o risco que se corre e às vezes se percebe é a elaboração de uma ética da biotecnia incapaz de incorporar a dimensão social que integra tudo o que é verdadeiramente humano".

Essas preocupações nos levam a fazer com que a Bioética seja uma disciplina encarnada na realidade latino-americana e, portanto, passe a refletir sobre temas relevantes à nossa sociedade. Além disso, não se pode dizer que alguns temas específicos da Bioética, como as implicâncias éticas do desenvolvimento científico, no campo da genética, por exemplo, sejam insignificantes para a América Latina. Repensar a Bioética a partir da América Latina, ou valorizar sua dimensão social, não é apenas inserir "novos temas", muito menos excluir outros (SANCHES, 2004, p. 14), significa sim reformular todos os temas da Bioética a partir de uma visão que seja condizente com a realidade social, econômica, política, histórica, cultural e religiosa de nosso continente. Seria um erro simplesmente importar a Bioética dos países ricos para a América Latina, mas também seria um erro ignorar o desenvolvimento da Bioética naqueles países.

\section{Impacto do avanço da biologia sobre nossa visão de mundo}

A reflexão crítica em educação não pode ignorar o impacto que o avanço das biociências provoca na visão de mundo atual. A partir do conhecimento do seu genoma, o ser humano está sendo envolvido por um processo de redefinição de si mesmo. Não foi apenas o Projeto Genoma Humano que colocou questionamentos a respeito da maneira como o pensamento tradicional da sociedade ocidental entende a questão de quem é o ser humano. Esta pergunta é antiga e a cada passo a humanidade insiste em interrogar-se. Entendemos, porém, que o conhecimento do nosso próprio genoma fecha uma etapa no conhecimento científico no campo da biologia, etapa essa iniciada no final do século XIX, a partir de Darwin.

Darwin desestabiliza o pensamento ocidental, demonstrando que todas as espécies, inclusive a humana, não estão acabadas e prontas, mas em processo de evolução. Agora, com o conhecimento do genoma, a humanidade é colocada nua diante do espelho e cada um de seus elementos biológicos está sendo conhecido. Nesse momento recoloca-se a pergunta: O que é o ser humano?

Rev. Diálogo Educ., Curitiba, v. 8, n. 23, p. 277-287, jan./abr. 2008 
E algumas perguntas nascem do receio da resposta, como a interrogação feita por Carol Tauer (1999, p. 104): "Existem coisas a respeito de nós mesmos que seria melhor não conhecer?"

Enquanto alguns manifestam preocupação a respeito das conseqüências práticas do conhecimento recém-adquirido no campo da biologia molecular (SMITH, 2000, p. 52), outros estão preocupados com o impacto que esse conhecimento terá sobre o que pensamos de nós mesmos. A biologia pode influenciar nossa visão de mundo muito antes dos cientistas conseguirem realizar alterações genéticas significantes. Isso porque a imagem que temos de nós mesmos é construída culturalmente e, como afirma Levi-Strauss (1983, p. 41), "os patrimônios culturais evoluem muito mais rapidamente do que os patrimônios genéticos".

A metáfora de que somos determinados pelos nossos genes é tida como muito forte, pois conhecendo os genes saberemos quem somos. Nesse sentido, Wilkie (1994, p. 210) afirma que, talvez, a mais inquietante conseqüência do projeto genoma será a difusão de que "o ser humano não é mais do que a expressão biológica do programa de instruções codificadas em seu DNA". É claro que temos aí a perspectiva do reducionismo biológico. Mesmo não aceitando o aspecto reducionista, temos que admitir, como afirma Matt Ridley (1999, p. 5), que sendo capazes de ler o genoma humano, passamos a conhecer mais sobre nossas origens, nossa evolução, nossa natureza e nossa mente, do que todas as ciências conseguiram até agora. Isso vai revolucionar a antropologia, a psicologia, a medicina, a teologia e praticamente todas as ciências. "Isto não significa afirmar que tudo está nos genes, ou que os genes são mais importantes do que outros fatores. Certamente não, isto está claro, mas que eles são importantes, não há dúvida."

É necessário evitarmos as posições radicais e entusiastas, marcadas pela euforia das descobertas. Também não devemos subestimar, nem negar a novidade que está diante de nós. Pensar a respeito do ser humano no presente sem incorporar os conhecimentos da pesquisa em genética, seria uma imperdoável omissão. De fato, no início do século XXI, a antropologia tem um novo ponto de partida. Anderson (1998, p. 68) afirma que os genes são ontologicamente necessários para a existência humana, ou seja, são indispensáveis para que os seres humanos possuam qualquer qualidade que seja considerada humana. Desse modo, qualquer discussão a respeito da natureza humana que ignore completamente a genética estará seriamente incompleta.

Frente a estas questões, o desafio está em fazermos uma avaliação equilibrada, pois valorizar a genética não significa negar a experiência e a importância das relações. Pois o ser humano constata, repetidas vezes, que suas experiências mais profundas de humanidade se produzem ali onde pode viver

Rev. Diálogo Educ., Curitiba, v. 8, n. 23, p. 277-287, jan./abr. 2008 
algum momento de adequação entre ele e os outros, ainda que seja em experiências fragmentárias ou parciais. O ser humano não pode ser visto como um "robô", programado pelos genes, mas como ser voltado aos demais. Essa referência aos outros entrecruza toda a existência humana de mil maneiras: em forma de necessidade, em forma de alegria pela companhia, em forma de sociedade, de família, de sexualidade, de unificação do planeta, em forma de responsabilidade. Por outro lado, o ser humano pode facilmente matar o seu irmão. Mas o que não pode de modo algum é ignorar que aquele a quem matou era seu irmão. A fraternidade é a meta última dessa "aventura" criadora, que quis ser a participação no Ser do Criador que é Comunhão (FAUS, 1987, p. 666-669).

O existencialismo contemporâneo, da mesma forma que outras filosofias que o precederam, como que ofuscado pela visão exclusiva do ser humano, costuma atribuir-lhe como homenagem especial, mas ao mesmo tempo também como uma carga, muita coisa baseada na existência orgânica como tal; com isso, a compreensão do mundo orgânico é privada das visões que a autopercepção humana lhe oferece, ao mesmo tempo em que deixa de ver a verdadeira linha divisória entre o animal e o ser humano. Por sua vez, a biologia científica, cujas regras a mantêm presa aos fatos físicos exteriores, é forçada a ignorar a dimensão da interioridade, que faz parte integrante da vida; com isso, ela faz desaparecer a distinção entre "animado" e "inanimado"; e ao mesmo tempo o sentido da vida, quando explicado unicamente pela matéria, torna-se mais enigmático do que antes. Ao buscar consolidar-se isoladamente, cada um deles sofre prejuízo - tanto a compreensão do ser humano quanto a da vida extra-humana (JONAS, 2004, p. 7).

\section{Superando uma perspectiva antropocêntrica arrogante}

A demonstração científica de que somos uma espécie entre outras, seres vivos como os outros, coloca necessariamente a pergunta sobre a especificidade dos seres humanos (WILSON, 1981, p. 17). O antropocentrismo, a doutrina que entende serem os seres humanos superiores aos outros animais, crença básica da cultura ocidental, é colocado em discussão (MUGNOZZA, 1996, p. 622). O relato complexo sobre a origem humana oferecido pela biologia contemporânea não apresenta clara distinção entre os humanos e os outros animais. Assim, a pergunta surge automaticamente: "Seriam os nossos primeiros ancestrais hominídeos humanos, ou somente os humanos modernos são verdadeiramente humanos?” (MURPHY, 1998, p. 11).

Uma definição de nós mesmos feita pela biologia indica logo que o velho antropocentrismo arrogante é, antes de qualquer coisa, uma insensatez. Somos seres vivos, do reino animal, pertencemos ao filo Chordatae, parte do subfilo

Rev. Diálogo Educ., Curitiba, v. 8, n. 23, p. 277-287, jan./abr. 2008 
vertebrata o qual compartilhamos com os peixes, anfíbios, répteis, aves e mamíferos. Entre os vertebrados, encontra-se a grande maioria das espécies que tem capacidade de sentir dor. Pertencemos à classe dos mamíferos, à ordem dos primatas - a qual compartilhamos com os lêmures, pequenos macacos, grandes macacos e outros humanos. Dentre os primatas, somos pertencentes à subordem dos Anthropoidea, formada pelos grandes macacos.

A linha que separa os chimpanzés, gorilas e humanos se dividiu há uns cinco milhões de anos, surgindo assim a família hominidea, à qual pertencemos e compartilhamos com os gêneros ramapithecus e australopithecus. As espécies pertencentes à família dos hominídeos são não menos do que 13 e o número de "novas" espécies crescerá com o progresso da ciência. Somos, portanto, do gênero Homo, que surgiu há cerca de dois milhões de anos e deu origem a outras espécies consideradas humanas, e hoje extintas: Homo Rudolfensis, Homo Habilis, Homo Ergaster, Homo Erectus, Homo Antecessor, Homo Heideibergensis, Homo Neanderthalensis (HOWELLS, 1993, p. 13). Por fim, somos a espécie Homo sapiens sapiens, humanos modernos - ou simplesmente Homo sapiens - surgidos por volta de 150 mil anos atrás na África, com muita vontade de se expandir e conhecer o mundo.

Esta descrição que nos situa entre os seres vivos, e mais especificamente entre os outros animais, de maneira alguma nos diminui, apenas mostra aquilo que somos: membros desta bela criação, parte integrante e ativa da natureza que apresenta entre as suas riquezas alguém capaz de descrevê-la e estudála. Deixamos claro num outro trabalho (SANCHES, 2004, p. 116) que a nossa abordagem da natureza será sempre antropocêntrica, mas não precisa, não deve e nem pode ser arrogante. Será sempre o humano que define a natureza, mas faz muita diferença colocar a si mesmo fora da natureza ou como parte integrante dela. A nossa perspectiva de análise e nossa linguagem jamais deveria falar da criação como se não fôssemos criaturas, falar dos animais numa oposição aos humanos, como se não pertencêssemos a mesmo reino.

Talvez tenhamos de concluir que a quantidade de DNA não indica muito a complexidade de um organismo, nem de sua relação com outros organismos. Isso porque, enquanto os humanos têm 46 cromossomos (23 pares), o gado bovino tem 60 , os cães e as galinhas ambos têm 78 . O número de cromossomos também não indica a quantidade de DNA, pois os sapos têm apenas 26 cromossomos, mas têm muito mais DNA que os humanos (HUBARD; WALD, 1993, p. 53).

\section{A vivência da interdisciplinaridade}

O debate sobre bioética não pode se resumir a um diálogo, ou quase monólogo entre os estudiosos do assunto. Entendemos, no entanto, que estudiosos devem servir de facilitadores para que o debate ocorra no seio dos diversos

Rev. Diálogo Educ., Curitiba, v. 8, n. 23, p. 277-287, jan./abr. 2008 
seguimentos de nossa sociedade. Aqui deve ser destacado o pluralismo cultural e religioso, cada vez mais evidente em nosso continente. Enquanto este debate não ocorrer de fato, não podemos falar verdadeiramente em Bioética Latino-Americana, ou seja, somente o debate aberto poderá corresponder ao desafio apontado por Pessini (1996, p. 18), que "é desenvolver uma bioética latino-americana que corrija os exageros das outras perspectivas e que resgate e valorize na cultura latina o que lhe é único e singular, uma visão verdadeiramente alternativa que possa enriquecer o diálogo multicultural".

A Bioética está num processo de amadurecimento no Brasil e é preciso que profissionais de diferentes áreas - pois a interdisciplinaridade é uma das marcas da bioética - se dediquem cada vez mais ao seu estudo e desenvolvimento, com pesquisas e reflexões verdadeiramente adaptadas à nossa realidade. Buscando respostas para a nossa realidade e com perspectivas e critérios nossos, talvez possamos afirmar que estamos construindo de fato uma Bioética Latino-americana. É desejável também que a bioética adquira visibilidade social, que saia dos círculos de reflexões das universidades para as ruas, pois as causas que ela defende são cruciais para o bem de toda a sociedade. Ninguém pode ficar indiferente, pois a bioética "envolve os profissionais da saúde e todos aqueles que, com competência e responsabilidade, dispõem-se a refletir eticamente sobre a melhor conduta a ser prestada à pessoa humana, à sociedade, ao mundo animal e vegetal e à própria natureza" (CORREIA, 1996, p. 36).

É neste contexto de diálogo interdisciplinar que a teologia também apresenta a sua contribuição, ciente de seu valor e de que representa apenas uma das muitas possíveis perspectivas. É bem verdade que a grande ocupação da teologia por meio do seu discurso, documentos oficiais e práxis, foi marcadamente ética com questões relativas à vida. Mas é sabido que isso não lhe dá nenhuma exclusividade no diálogo interdisciplinar da Bioética. Suas razões e fundamentos estão associados estreitamente à fé, corroborando para tal, que a teologia é facilmente circunscrita às convicções do grupo que a elabora, restringindo a força de suas contribuições. O "discurso religioso" veiculado pela teologia na bioética ainda é recebido de formas variadas, entre a simpatia e a antipatia, a indiferença, a desconfiança, a integração e a total separação (ANJOS, 2003, p. 455-456).

A teologia no debate bioético sobre as biotecnociências aplicadas ao ser humano ajuda a recordar duas dimensões antropológicas essenciais: 1) a consciência da vulnerabilidade que leva a aceitar e a transignificar as limitações pessoais, base para a constituição da subjetividade e da correspondente autonomia; 2) a consciência da alteridade que leva a reconhecer o outro como o outro diferente, base para as relações intersubjetivas e de correspondente responsabilidade (JUNGES, 2005, p. 114-115). A vida segundo o espírito manifesta-se como a vida propriamente humana. Ela o é justamente em virtude

Rev. Diálogo Educ., Curitiba, v. 8, n. 23, p. 277-287, jan./abr. 2008 
da correspondência transcendental entre o espírito e o ser. Com efeito, viver para os seres vivos é seu próprio existir. E como o ser humano existe em sua abertura transcendental para a universalidade do ser ou em sua adequação ativa como ser, ele existe verdadeiramente enquanto espírito, ou a vida propriamente humana é a vida segundo o espírito.

Por fim, gostaríamos de indicar, para ser aprofundado num outro momento, que o caráter interdisciplinar e plural da bioética é concretamente vivenciado nos diferentes comitês de Bioética, sendo um deles o Comitê de Ética em Pesquisa, que avalia eticamente todas as pesquisas que envolvem seres humanos. A resolução que criou este comitê define claramente que "sua composição deverá incluir a participação de profissionais da área de saúde, das ciências exatas, sociais e humanas, incluindo, por exemplo, juristas, teólogos, sociólogos, filósofos, bioeticistas e, pelo menos, um membro da sociedade representando os usuários da instituição" (MS, Resolução 1967/96, VI.4). É interessante destacar a relevância da Educação para a Bioética, pois é ela que nos oferece ferramentas para uma compreensão mais profunda do que é inter, multi ou transdisciplinaridade. Desse modo, é muito bem vindo o efetivo e crescente envolvimento de muitos peritos em educação no debate sobre Bioética e nas rotinas dos comitês.

\section{REFERÊNCIAS}

ANDERSON, V. Elving. A genetic view of human nature, In: BROWN, Warren S.; MURPHY, Nancey; MALONY, Newton H. Whatever happened to the soul? scientific and theological portraits of human nature. Minneapolis: Fortress Press, 1998, p. 68.

ANJOS, Márcio Fabri dos. Bioética a partir do Terceiro Mundo. In: ANJOS, Márcio Fabri dos (Org.) Temas latino-americanos de ética. Aparecida: Santuário, 1988, p. 211-232.

BEUCHAMP, Tom L.; CHILDRESS, James F. Principles of biomedical ethics. Oxford: Oxford University Press, 1994.

CHARDIN, Teilhard. Sobre o amor. São Paulo: Record, 1969.

DURAND, Guy. Introdução geral à bioética. São Paulo: Loyola e São Camilo, 2003.

CORREIA, Francisco de Assis. Alguns Desafios Atuais da Bioética. In: PESSINI, Leo; BARCHIFONTAINE, Christian de Paul (Org.). Fundamentos da bioética. São Paulo: Paulus, 1996. p. 30-50.

Rev. Diálogo Educ., Curitiba, v. 8, n. 23, p. 277-287, jan./abr. 2008 
FAUS, José Ignácio Gonzalez. Proyecto de hermano: visión creyente del hombre. Santander: Sal Terrae, 1987.

GARRAFA, V.; PORTO, D. Bioética, poder e injustiça: por uma ética de intervenção. In: GARRAFA, V.; PESSINI, L. Bioética: poder e injustiça. São Paulo: Loyola, 2003. p. 35-44.

GRECO, Dirceo. A questão do duplo standard. In: CONGRESSO BRASILEIRO DE BIOÉTICA, 6., 2005. Foz do Iguaçu. Anais... Foz do Iguaçu: Publicações de Governo, 2005. p. 36.

HOWELLS, William. Getting here: The story of human evolution. Washington: The Compass Press, 1993.

HUBBARD, Ruth; WALD, Elijah. Exploding the gene myth: how genetic information is produced and manipulated by scientists, physicians, employers, insurance companies, educators, and law enforcers. Boston: Beacon Press, 1993, p. 53.

JONAS, Hans. The imperative of responsibility. In: Search of an ethics for technological age. London: University of Chicago Press, 1984. p. 21.

O princípio vida. fundamentos para uma biologia filosófica. Petrópolis: Vozes, 2004.

JUNGES, José Roque. As Interfaces da Teologia com a Bioética. Perspectiva Teológica, Belo Horizonte, Ano 37, n. 101, p. 105-122, jan./abr. 2005.

LÉVI-STRAUSS, Claude. O olhar distanciado. Lisboa: Edições 70, 1983. 41 p.

MACKLIN, Ruth. Bioética, vulnerabilidade e proteção. In: GARRAFA, V.; PESSINI, L. Bioética: Poder e Injustiça. São Paulo: Loyola, 2003. p. $59-70$.

MUGNOZZA, Gian Tommaso Scarascia. Ethics of biodiversity conservation, In: CASTRI, Francesco di; YOUNĖ, Talal. Biodiversity, science and development: towards a new partnership. Paris: IUBS / CAB International, 1996. p. 622-629. 
MURPHY, Nancey. Human nature: historical, scientific, and religious issues, In: BROWN, Warren S.; MURPHY, Nancey; MALONY, Newton H. Whatever happened to the soul? scientific and theological portraits of human nature. Minneapolis: Fortress Press, 1998. p. 11.

PESSINI, Léo. O Desenvolvimento da bioética na América Latina. In: PESSINI, Leo, BARCHIFONTAINE, Christian de Paul. (Org.). Fundamentos da bioética. São Paulo: Paulus, 1996. p. 9-29.

RIDLEY, Matt. Genome: the autobiography of a species in 23 chapters. New York: HarperCollinsPublishers, 1999.

SANCHES, Mário Antonio. Bioética ciência e transcendência. São Paulo: Loyola, 2004.

SCHRAMM, Fermin Roland. Bioética e biossegurança. In: COSTA, S. I. F.; OSELKA, G.; GARRAFA, V. (Coord.). Iniciação à bioética. Brasília: Conselho Federal de Medicina, 1998. p. 217-230.

SIQUEIRA, José Eduardo de. O princípio da justiça. In: COSTA, S. I. F, OSELKA, G., GARRAFA, V. (Org.). Iniciação à bioética. Brasília: Conselho Federal de Medicina, 1998, p. 71-80.

SMITH J. Wesley. Culture of death: the assault on medical ethics in America. San Francisco, California: Encounters Books, 2000.

TAUER, Carol A. The human significance of the genome project (1992). In: SHANNON, Thomas A. (Ed.). Genetic engineering: a documentary history. London: Greenwood Press, 1999, p. 103-110.

WILKIE, Tom. Projeto genoma humano: um conhecimento perigoso. Rio de Janeiro: Jorge Zahar, 1994.

WILSON, Edward O. Da natureza humana. São Paulo: T.A. Queiroz, 1981.

Recebido: 02/07/2007

Received: 07/02/2007

Aprovado: 05/11/2007

Approved: 11/05/2007

Rev. Diálogo Educ., Curitiba, v. 8, n. 23, p. 277-287, jan./abr. 2008 